\title{
Application of WeChat in English Teaching
}

\author{
Ying Wei \\ Foreign Language School \\ Huanghe Science and Technology University \\ Zhengzhou, China
}

\begin{abstract}
With the development of multimedia teaching in colleges and universities, English curriculum more and more focus on the combination of interactive teaching concept and teaching practice. The full implementation of interactive teaching more effectively creates a good environment for students to learn English. WeChat, as a new communication mode and an interactive platform, boasts its voice communication, rapidness and convenience. WeChat, widely spread and applied in college English teaching, provides a new direction for the development of online English teaching. This paper, on basis of the main function of WeChat software, offers a brief description of the advantages of WeChat software application in College English and then summarizes its application modes in order to provide good references for College English teaching.
\end{abstract}

Keywords-WeChat; college English teaching; application

\section{CHARACTERISTICS AND AdVANTAGES OF WECHAT APPLICATION IN ENGLISH TEACHING}

\section{A. To Form Students'Learning center, and Fully Inspire the Students' Subjective Motivation}

As a multi-functional teaching tool, WeChat with pictures, sound and group chat and other functions can make up the defects of boring and simplicity in traditional teaching methods. In this case, various classroom teaching materials can effectively stimulate students' learning motivation; in addition, the use of WeChat's voice function can help students to get rid of the nervous emotion of the face-to-face communication, which will better achieve the purpose of oral practice. WeChat's diverse functions are the inherent advantages of its application in English teaching, for example, WeChat immediate communication meets students' daily living habits, and better motivates students' learning interest and enthusiasm; variety of teaching materials as well as can help students to strengthen the understanding of the teaching content. Students become the center of the classroom teaching and fully play the principle role to further meet the requirements of the new curriculum.

\section{B. To Improve the Content and Efficiency of English Tteaching}

WeChat's application further improve students' communication of learning experience through the mobile phone terminal at any time, such as group chat function makes it feasible to provide a platform for class discussion. Communication at anytime and anywhere overturns the traditional English teaching, and more English learning happens out of classroom. Students can arrange their study according to their actual situation, and teachers can publish some supplementary materials through WeChat. In addition, students can exercise their writing skills and grammar points in the process of discussion, strengthen listening ability though WeChat's voice function. As for homework, students upload their homework, and teachers check it on WeChat platform to sum up some common mistakes. In this case, students' learning effects are improved, and teachers arrange the learning content and speed very well.

\section{THE POSSIBILITY OF WECHAT INTEGRATION TO COLLEGE ENGLISH TEACHING}

With the development of smart phones and multimedia technology, multimedia teaching is bound to become the main teaching method. WeChat, a multimedia teaching tool combining phone terminal provides an independent, personalized learning platform for students, which can enrich students' learning materials and teacher's teaching means, replace the boring and serious teaching atmosphere. In the enlivened and harmonious classroom atmosphere, students' active thinking will increase, and students' knowledge and understanding will be deepened and strengthened. What's more, teachers can publish teaching materials on WeChat ahead of class, and students self-study the given contents according to their own conditions. In that condition, teachers will be able to focus not on the blackboard writing or the new knowledge teaching, but on learning about students' learning efficiency and illustrating the problems they are encountered with, which will greatly enhance students' learning efficiency. Teachers can apply WeChat to introduce some helpful materials, such as films, songs, or some websites, which can enrich students' second classroom.

\section{WeChAT APPLICATION MODELS IN COLLEGE ENGLISH TEACHING}

\section{A. Student-centered Interactive Teaching Mode}

In the course of College English teaching, listening, speaking, reading, writing and translating abilities are essential. WeChat can be used to build a online teaching platform between teachers and students. Teachers release English articles and curriculum knowledge on WeChat to let students check and receive the materials also on WeChat platform. Then students are expected to improve their reading skills and enhance their knowledge mastery in the 
process of doing homework assigned on the WeChat. In addition, teachers can accomplish error correction, grammar errors' modification on WeChat platform insistently to enhance students' comprehensive English level and learning confidence. WeChat platform not only provides a great convenience to college English teaching, but also facilitates the practice of listening, speaking, reading, writing and translating abilities to students. So it can be said that WeChat can further promote the development of College English teaching, and keep students' active thinking for a long time.

\section{B. Emotion Supply Mode}

The application of WeChat in College English teaching and learning has effectively made up the lack of emotional communication between teachers and students. As for teachers, they can communicate with students at any time to facilitate a more in-depth understanding of their study situation and emotion status, and take students' views and suggestions for future curriculum design. From the perspective of College students, WeChat's application in the English curriculum effectively makes up for the lack of emotional communication between teachers and teachers. On WeChat platform, teachers provide guidance and help, which will greatly enhance the student's emotional satisfaction and arise their enthusiasm for English studying.

\section{Combination of Input and Output Mode}

In the process of WeChat application in College English class, teachers are able to publish text, pictures, video and other content, and combine grammar contents and knowledge points with WeChat's functions. In this case, teaching contents are presented in a new form, which will greatly attract students' attention and response instantly. Students are willing to read and listen the materials that teachers publish, and give comments to others' saying or opinions through oral and written English. What's more, WeChat's rapid update speed of materials and instant communication function can effectively combine students' input and output of English learning, beneficial to students' comprehensive English ability.

\section{NOTES OF WECHAT APPLICATION IN COLLEGE ENGLISH TEACHING}

\section{A. To Emphasize the Major Role of Classroom Teaching}

WeChat's integration in College English teaching not only provides a new platform for English learning, but also creates opportunities of recreational learning for students. But actually, some students may be immersed in game entertainment, ignoring the nature of learning the learning process on WeChat platform. To get rid of the negative influence of entertainments on WeChat, teachers should emphasize the major role of class teaching, and try to turn WeChat into an interactive English learning platform and make WeChat teaching environment be fully optimized. But WeChat English Teaching is still limited by the nature of WeChat's itself. College English teaching should stick to the major role of classroom teaching, and check the subject of
English teaching timely, to ensure that college English teaching and learning effectively develop.

\section{B. To Emphasize the Evaluation of WeChat Application}

In order to guarantee the teaching quality of college English, we must check and revise WeChat teaching platform timely, in order to promote WeChat's correct application and stable development. WeChat-based college English teaching fully explores space and time resources, which are required to have positive effects to students' learning. And WeChat evaluation system is needed to build, which can play a role as a good monitor in WeChat application. Through the evaluation of WeChat's effects on students' learning behaviors and learning efficiency, teachers could better understand the practical effects of WeChat application, and further to realize the transition from traditional boring teaching mode to a modernized online English teaching mode.

\section{CONCLUSION}

With the rapid development of science and technology in our country, under the impetus of instant communication technology, WeChat's application in college English teaching is of great significance. It fully demonstrates the trend of online interactive teaching, and at the same time, it has greatly enriched the teaching of college English. If WeChat is converted into an English teaching tool, it will greatly enhance the flexibility of college English teaching, and to a deeper degree, promote the formation of students' autonomous learning and cooperative learning atmosphere. As contemporary college English teachers, we should not only pay attention to the students' professional knowledge in the teaching process, but also the introduction and integration of modern teaching techniques in practical teaching, to fully make full use of the advantages of modern technology in college English teaching.

\section{REFERENCES}

[1] Jiang Hongmei. Using the writing in micro-blog to improve Higher Vocational Students' English grammar [J]. Journal of Hebei United University, 2012 (3): 63-64.

[2] Jing Le Gang, Lu Fang. How to improve the teaching effect of multimedia [A]. Zhao Min. Research and practice of higher education reform [C]. Harbin: Heilongjiang people's publishing house, 2003

[3] Hao Zhaojie, Sun Zhongna. Wrapping Collar to the College English Teaching [J]. modern educational technology, 2010 (6): 63-65.

[4] Pan Deng. A Study on the Adaptability of the Micro Learning Community in Mobile English Learning-Oral English Training for English Majors Based on WeChat [J]. Journal of Hubei University of Science, 2013 (9): 103-105.

[5] Wang Ping. The Analysis of Support Function and Design Principles of WeChat Mobile Learning [J]. Distance Education Journal, 2013 (06)

[6] Zheng Shutang. The teaching reform of College English and New Horizon College English [M]. Beijing: foreign language teaching and Research Press, Beijing foreign language audio visual press, 2003 